\title{
Effects of Feeding Processed Kidney Bean Meal (Phaseolus vulgaris) by Replacing Soybean Meal on Egg Fertility and Qualities of Chicks of White Leghorn Hens
}

\section{Taju Hussein ${ }^{1 *}$, Mengistu Urge ${ }^{2}$, Getachew Animut ${ }^{2}$ and Sisay Fikru ${ }^{3}$}

${ }^{1}$ Depertment of Animal and Range Science, Collage of Agriculture, Wolaita Soddo University, Ethiopia; Po. Box 138, Wolaita Soddo, Ethiopia

${ }^{2}$ Department of Animal and Range Science, College of Agriculture and Environmental science, Haromaya University, Ethiopia, po. Box, 138 Dire Dawa, Ethiopia

${ }^{3}$ Depertment of Animal and Range Science, Collage Dry Land Agriculture, Jig-jiga University, Ethiopia; Po. Box 1020 Jig-jiga, Ethiopia

\begin{abstract}
A study was conducted to evaluate the effects of feeding processed kidney bean meal (PKBM) by replacing soybean meal (SBM) on fertility, hatchability, embryonic mortality and chick quality of white leghorn (WL) hens. A total of 210 white leghorn hens (180 layers and 30 cocks) with uniform body weight (BW) $(1121.17 \mathrm{~g} \pm 24.92)$ and age (6.5 months) were randomly distributed into 15 pens and assigned to five treatments (i.e., T1, T2, T3, T4, and T5). A total of 195 eggs collected from all the treatment birds were used for the analysis. The feeds of the treatments were SBM substituted by PKBM at 0, 25, 50, 75 and 100\% levels for T1, T2, T3, T4, and T5, respectively. Replacement of SBM with PKBM in the diet did not affect the fertility, hatchability and embryonic mortality. Chick length (15.63, $15.00,15.33,15.03$ and 14.33 (SEM \pm 0.02$)$ ) and chick weight $(34.13,34.20,33.13,33.06$ and $32.47(\mathrm{SEM} \pm 1.39)$ ) for T1, T2, T3, T4 and T5 respectively, were significantly $(P<0.05)$ lower for T5 than the rest treatments. Visual assessment of chick quality is lower for treatments containing higher proportion of PKBM than treatments containing lower proportion of PKBM. Therefore, as it affects the quality of chicks at $100 \%$ replacement, it is only up to $75 \%$ replacement of SBM by PKBM (dosed at $195 \mathrm{~g} / \mathrm{kg}$ concentrate diet) is possible without having significant negative effect on chick quality.
\end{abstract}

Keywords: Embryonic mortality; Fertility; Hatchability; Kidney bean; Soybean meal

\section{Introduction}

Chick quality is affected by pre-incubation storage conditions, time in the Hatcher, and size of egg. Tona et al. found that increased incubation storage produced poor quality chick. Larger eggs tend to have significantly poor quality chicks as compared to other egg size [1].

The fertility of an egg is affected by several factors originating from the hen such as her ability to mate successfully, to store sperm, to ovulate an egg cell, and to produce a suitable environment for the formation and development of the embryo. The fertility also depends on the cock's ability to mate successfully, quantity and quality of semen deposited [2]. When fertility is low, it can affect other categories because of the lack of uniformity of embryo temperature inside the egg set (not as much heat provided by the developing embryos).

Hatchability is a process that has several critical points that can be monitored and controlled to produce consistently healthy and mature hatchlings. These includes assessing hatching egg, fertility, egg storage and care, evaluation of hatch residue, poultry processing, sanitation, and poultry health and viability [3].

Kidney bean (Phaseolus vulgaris), is one of the neglected grain legume among the tropical legumes. Kidney bean can be used to fortify cereal-based diets especially in developing countries, because of its high protein content [4]. It is also a rich source of vitamin, minerals and relatively high in crude fiber. Kidney bean is one such protein source, which when used in the fortification or enrichment of cerealbased diets could go a long way in improving their nutritional status [5]. Weight gain and feed consumption were significantly reduced, and feed efficiency was increased in birds fed raw kidney bean (RKB) compared with those fed the control diet.
The cost of poultry feed is very high and it accounts for $60-70 \%$ of the layer production cost [6]. In recent years, the price of conventional or basic feed ingredients has tremendously increased. This has made poultry and live-stock production very expensive. In Ethiopia where soybean and its meal are in short supply and very expensive, the use of soybean meal as protein source of poultry ration is limited. Thus, an alternative protein source should be assessed and used. Sisay et al. suggested that $100 \%$ replacement of SBM with PKBM is possible at $10 \%$ $(100 \mathrm{~g} / \mathrm{kg})$ of soybean in layer ration. Therefore, the present research was initiated to evaluate the effect of feeding processed kidney bean meal (Phaseolus vulgaris) by replacing soybean meal at 19.5\% (195 g/ $\mathrm{kg}$ ) on egg fertility and qualities of chicks of white leghorn hens [7].

\section{Materials and Methods}

\section{Study site}

The experiment was carried out at Haramaya University Poultry Farm located at $42^{\circ} 3^{\prime}$ E longitude, $9^{\circ} 26^{\prime} \mathrm{N}$ latitude and situated at an altitude of 1980 meter above sea level, and $505 \mathrm{~km}$ east of Addis Ababa. The site has mean annual rainfall of $780 \mathrm{~mm}$ and the average minimum and maximum temperatures of $8^{\circ} \mathrm{C}$ and $24^{\circ} \mathrm{C}$ respectively.

*Corresponding author: Taju Hussein, Department of Animal and Range Science, Collage of Agriculture, Wolaita Soddo University, Wolaita Soddo, Ethiopia, Tel: +251921241830; E-mail: tajuh47@gmail.com

Received May 16, 2015; Accepted June 25, 2015; Published June 27, 2015

Citation: Hussein T, Urge M, Animut G, Fikru S (2015) Effects of Feeding Processed Kidney Bean Meal (Phaseolus vulgaris) by Replacing Soybean Meal on Egg Fertility and Qualities of Chicks of White Leghorn Hens. J Veterinar Sci Technol S12: 001. doi:10.4172/2157-7579.S12-001

Copyright: ( 2015 Hussein T, et al. This is an open-access article distributed under the terms of the Creative Commons Attribution License, which permits unrestricted use, distribution, and reproduction in any medium, provided the original author and source are credited. 
Citation: Hussein T, Urge M, Animut G, Fikru S (2015) Effects of Feeding Processed Kidney Bean Meal (Phaseolus vulgaris) by Replacing Soybean Meal on Egg Fertility and Qualities of Chicks of White Leghorn Hens. J Veterinar Sci Technol S12: 001. doi:10.4172/2157-7579.S12-001

Page 2 of 6

\section{Management of experimental animals}

Experimental house which were partitioned into 15 pens with wiremesh and covered with grass litter material of $10 \mathrm{~cm}$ depth were used for experiments. Before the commencement of the actual experiment, the experimental pens, $\left(2.5^{\star} 2 \mathrm{~m}\right)$, watering equipment, feeding troughs and laying nests were disinfected, sprayed piperazine citrate (i.e., 900 $\mathrm{ml}$ in 20 lit water) against external parasites and thoroughly cleaned. Disinfectant was placed at the gate of the experimental house for workers and other visitors to step on before they enter into the house, which is in addition to the one placed at the main gate of poultry farm, for prevention of disease introduction.

The birds were vaccinated against Newcastle disease according to the vaccination program of the farm. The birds were randomly distributed in to 15 pens and offered with experimental diets for 7 days as period of adaptation before actual data collection takes places. The feed was measured and given to the birds in groups twice a day at 8 am and $2 \mathrm{pm}$ on ad libitum basis by dividing the daily offer into two equal portions. Feed refusals were collected every morning at 7:30 am before providing new feed, external contaminants were removed by visual inspection, weighed and recorded for each pen separately. Feed were offered into two metal tubular feeders per pen that was hanged approximately at a height of the backs of the birds. Water was provided in a plastic fountains placed on a flat stone at the center of the pen. The watering trough was cleaned every morning before feeding. Clean and fresh water was available to the birds' ad libtum. The experimental duration lasted for 12 weeks.

\section{Treatments and experimental design}

The ration of the experiment consists of $\mathrm{PKB}$, which replaced SBM at five levels, namely $0,25,50,75$ and $100 \%$ PKB for T1, T2, T3, T4 and $\mathrm{T} 5$, respectively (Table 1). Initially weighed two hundred ten (210) birds consisting of 180 White leghorn layers and 30 cocks (14 birds per pen) of mature white leghorn breeds of similar age and weight, which were obtained from the University's poultry farm, were randomly assigned to the five treatment rations. Thus, the design employed was a completely randomized design (CRD) with five treatments and three replications (pen) per treatment (Table 1).

\section{Chemical composition of experimental feeds}

Representative samples of feed ingredients was taken and analyzed before formulating the actual dietary treatment rations. The results of the analysis were used to formulate the treatment rations (Table 2). The feed ingredient offer samples were analyzed for dray matter (DM), ether extracts (EE), crude fiber (CF) and ash following the procedure of Weende (proximate analysis method) [8]. Kjeildhal procedure was employed to determine the nitrogen $(\mathrm{N})$ content of the feeds and crude protein $(\mathrm{CP})$ was determined by multiplying the $\mathrm{N}$ value with 6.25. The total metabolizable energy (ME) contents were calculated indirectly by using the formula presented by Wiseman [9]. ME (Kcal/ $\mathrm{kg} \mathrm{DM})=3951+54.4 \mathrm{EE}-88.7 \mathrm{CF}-40.8$ Ash.

\section{Data collection and measurements}

Fertility and hatchability: Hundred ninety-five, that is 39 and 13 eggs from each treatment and replication, respectively, of medium sized, non-defected and normal shaped eggs were collected in three consecutive days. The eggs were kept at room temperature until incubated within 4 days after the first day of collection. The eggs were lightly coded by marker before they were placed into the incubator. The incubation temperature and relative humidity during the 18 days of incubation was auto fixed at $37-38^{\circ} \mathrm{C}$ and $65-70 \%$, while that of hatchery unit was adjusted to $38.5-39^{\circ} \mathrm{C}$ and $90 \%$ relative humidity.

The eggs kept in the tray with small end down and turned automatically by slanting the tray at $45^{\circ} \mathrm{C}$. The incubator is equipped with the turner that facilitates the turning operation at an interval of two hours. Fertility was determined by candling the incubated eggs on the $7^{\text {th }}$ day of incubation. Candling was done at dark room with egg Candler powered by electricity. Eggs found to be infertile, which are characterized by clear appearance, egg with blood adhering to one sides of the eggs were drown from the incubator. Finally eggs found fertile, i.e. eggs having small dark spot, numerous blood vessels arising from those dark spot of yolk at day of candling, clearly visible thick and dark and well fill structure was further kept in the incubator for hatching [10]. Eggs with living embryo were transferred to the hatching section of the incubator at the end of the $18^{\text {th }}$ day. Hatched chicks were counted and chick quality was determined. Fertility and hatchability were determined by using the following formulae, respectively.

$$
\begin{aligned}
& \% \text { Fertility }=\frac{\text { number of fertile eggs }}{\text { total egg set }} \times 100 \\
& \% \text { Fertility }=\frac{\text { number of chick hatched }}{\text { fertile eggs }} \times 100
\end{aligned}
$$$$
\% \text { Hatchability on total eggs base }=\frac{\text { number of chick hatched }}{\text { total eggs set }} \times 100
$$

Embryonic mortality: Embryonic mortality was determined by candling eggs at $7^{\text {th }}, 14$ th and 18th days of incubation and at hatching. Eggs that had a structure encircled with blood ring, absence of blood vessels, adhering to the shell membrane and absence of clear demarcation between embryo and air cell was considered as dead embryo and removed from the incubator [10]. The dead embryo further categorized in to early, mid, late dead and pip embryo, based on

\begin{tabular}{|c|c|c|c|}
\hline Treatments & Replications & $\begin{array}{c}\text { Layers per } \\
\text { replication }\end{array}$ & $\begin{array}{c}\text { Cocks per } \\
\text { replication }\end{array}$ \\
\hline T1(100\%SBM:0\%PKB) & 3 & 12 & 2 \\
\hline T2 (75\% SBM:25\%PKB) & 3 & 12 & 2 \\
\hline T3 (50\% SBM:50\%PKB) & 3 & 12 & 2 \\
\hline T4 (25\% SBM:75\%PKB) & 3 & 12 & 2 \\
\hline T5 (0\% SBM:100\% PKB) & 3 & 12 & 2 \\
\hline
\end{tabular}

SBM: Soybean Meal; PKB: Processed Kidney Bean; 100\% PKB represents replacement of maximum SBM $(260 \mathrm{~g} / \mathrm{kg})$ as recommended by Senayt et al. [32].

Table 1: Experiment lay out.

\begin{tabular}{|c|c|c|c|c|c|}
\hline Feed (\%) & T1 & T2 & T3 & T4 & T5 \\
\hline CG & 56 & 53 & 52 & 48 & 37 \\
\hline WS & 7 & 7 & 7 & 7 & 16 \\
\hline SBM & 26 & 19.5 & 13 & 6.5 & 0 \\
\hline PKB & 0 & 6.5 & 13 & 19.5 & 26 \\
\hline NSC & 4 & 7 & 8 & 12 & 14 \\
\hline LS & 5.5 & 5.5 & 5.5 & 5.5 & 5.5 \\
\hline Salt & 0.5 & 0.5 & 0.5 & 0.5 & 0.5 \\
\hline VPM & 1 & 1 & 1 & 1 & 1 \\
\hline Total & 100 & 100 & 100 & 100 & 100 \\
\hline
\end{tabular}

CG: Corn Grain; WS: Wheat Short; SBM: Soybean Meal; PKB: Processed Kidney Bean; NSC: Noug Seed Cake; LS: Limestone; VPM: Vitamin Pre-mix T1 100\%SBM: 0\%PKB; T2: 75\%SBM: 25\%PKB; T3: 50\%SBM: 50\%PKB; T4 25\%SBM: 75\%PKB; T5: 0\%SBM: 100\%PKB.

Table 2: Proportion of feed ingredient used in formulating experimental rations. 
the classification criteria set by Butcher [11]. The embryonic mortality was computed by using the formulae indicated by Rashed [12].

$$
\% \text { Hatchability on total eggs base }=\frac{\text { number of chick hatched }}{\text { total eggs set }} \times 100
$$$$
\% \text { of early mortality }=\frac{\text { total number of early dead embryo }}{\text { total number of fertile eggs }} \times 100
$$$$
\% \text { of mid mortality }=\frac{\text { total number of mid dead embryo }}{\text { total number of fertile eggs }} \times 100
$$$$
\% \text { of late mortality }=\frac{\text { total number of late dead embryo }}{\text { total number of fertile eggs }} \times 100
$$

$$
\% \text { of pip mortality }=\frac{\text { total number of pip dead embryo }}{\text { total number of fertile eggs }} \times 100
$$

Chick quality: Chicks' quality were measured using two different methods, which includes visual scoring and measuring of day old chick weight and length. Visual scoring of chicks was done by visual examination based on the quality standards described by North [10]. Accordingly, a chick that was not malformed, physically active, stands up well, and looks live has been taken as good quality chicks. The researcher and two technicians were under taken the visual quality assessment. Based on common decisions, the chicks were classified in to poor and normal chicken. After the chicks were classified in to two groups, namely quality (chicks with dried body, stand well, and active) and non-quality chicks (chicks with wet body, not firm, non-straight, and not having perpendicular leg to the ground), five chicken from normal chicken were taken randomly from each replicate and their weight and length were measured using sensitive balance and ruler for further quality assessments respectively. The chick's length was taken by stretching the chicks on the table and taking the length from the tip of the beak to the middle toe by a ruler. Percentage of quality chicks were calculated as

$$
\text { Quality chicks }=\frac{\text { total number of quality chicks }}{\text { total number of hacthed chicks }} \times 100
$$

Statistical analysis and models: The data collected during the study period were subjected to statistical analysis using SAS computer software version 9.1.3. SAS during data analysis, chick weight and length were analyzed following one way analysis of variance procedure [13]. When the analysis of variance indicated the existence of significant difference between treatment means, Tukkey test method was used to locate the treatment means that were significantly different from the other [14].

The model used for statistical analysis was:

$$
\mathrm{Yij}=\mu+\mathrm{Ti}+\mathrm{eij}
$$

Where: Yij=Individual observation,

\section{$\mathrm{Ti}=$ Treatment effect, $\mu=$ Overall mean, eij=Error term}

General logistic regression analysis was employed for analysis of data recorded on fertility (fertile/infertile), hatchability (hatched/ un-hatched), embryonic mortality (alive/dead), and visual scoring (normal/poor). The general logistic regression model used is given below:

$$
\text { Model: } \operatorname{In}\left\{\frac{\pi}{1-\pi}\right\} \beta 0+\beta 1 *(x)
$$

Test H0: No treatment effect (i.e., $\beta 1=0$ ) vs.

HA: Significant treatment effect $(\beta 1 \neq 0)$.

Where, $\pi=$ probability,

$\beta=$ slope $x=$ treatment

\section{Results and Discussion}

\section{Nutrient composition of ingredients and the treatment}

The results of the chemical analysis of ingredients used and nutritional composition of the ration-for each treatment are given in Tables 3 and 4 respectively. The DM contents of PKB obtained in the present study was slightly lower than reported by Marzo et al. (93.2\%) and Audu and Aremu (96.8) but very close to Sisay et al., and Sisay et al. (88) [15-18]. While CP contents is slightly higher than reported by Marzo et al. Audu and Aremu, Emiola, Sisay et al., Sisay et al. and Emiola and Olghobo which were 20.9\%, 23.6\%, 24.7\%, 25.8\% and $26.8 \%$, respectively $[7,16,17,19-21]$. The EE content of kidney bean is the same with that reported by Emiola but Marzo et al. reported lower than the current results $[19,20]$. The CF content of kidney bean used in the present study was comparable to that reported by Arija et al., Emiola, Sai-ut et al., Audu and Aremu, Sisay et al., Sisay et al., who reported 5.1, 5.0, 6.0, 4.7\% and $4.5 \%$ respectively $[7,15-17,20,22]$. The result of chemical composition of kidney bean used in the present experiment showed comparable ME contents to that noted by Ofongo and Aloghobo and Arija et al. who reported 3342.2 and $3365 \mathrm{kcal} / \mathrm{kg}$, respectively $[15,23]$.

In general, as different report showed the processing (treatments) could cause drop or increase in nutrients compared to the raw seed. The treatment method (boiling) employed was suggested increased total carbohydrates and decrease the CP, EE, CF and ash contents $[16,19]$. Similarly Akaerue and Onwuka and Mubarak reported reduced $\mathrm{CP}, \mathrm{EE}, \mathrm{CF}$ and ash for Mung bean (Vigna radiata). The low

\begin{tabular}{|c|c|c|c|c|c|c|}
\hline \multicolumn{7}{|c|}{ Nutrient composition (\% for DM and\% DM for others) } \\
\hline Feed type & DM & CP & EE & CF & Ash & $\begin{array}{c}\text { ME kcal/ } \\
\text { kg }\end{array}$ \\
\hline CG & 89.5 & 8.7 & 4.3 & 8.0 & 6.21 & 3230.5 \\
\hline WS & 90.3 & 12 & 3.3 & 6.2 & 6.8 & 3303.1 \\
\hline SBM & 90.2 & 38 & 7.0 & 9 & 7.8 & 3215 \\
\hline PKB & 87.5 & 28 & 0.9 & 6 & 7.0 & 3182.2 \\
\hline NSC & 91.5 & 26 & 6.0 & 21.0 & 10 & 2006.0 \\
\hline
\end{tabular}

CG: Corn Grain; WS: Wheat Short; SBM: Soybean Meal; PKB: Processed Kidney Bean; NSC: Noug Seed Cake; DM: Dry Matter; CP: Crude Protein; EE: Ether Extract; CF: Crude Fiber; ME: Methabolizable Energy.

Table 3: Ingredient used in the study and its nutrients compositions.

\begin{tabular}{|c|c|c|c|c|c|c|c|c|}
\hline \multicolumn{10}{|c|}{ Nutrient composition (\% for DM and\% DM for others) } \\
\hline Treatments & DM & CP & EE & CF & Ash & Ca & P & ME kcal/kg \\
\hline T1 & 91.85 & 18 & 5.64 & 6.26 & 9.96 & 3.4 & 0.39 & 3296.20 \\
\hline T2 & 91.56 & 17.8 & 5.63 & 6.36 & 9.97 & 3.26 & 0.38 & 3286.40 \\
\hline T3 & 91.17 & 17.6 & 5.58 & 6.52 & 9.98 & 3.28 & 0.38 & 3269.00 \\
\hline T4 & 90.21 & 16.3 & 5.40 & 6.56 & 9.98 & 3.01 & 0.36 & 3255.70 \\
\hline T5 & 89.86 & 16.0 & 4.90 & 6.86 & 10.20 & 2.79 & 0.32 & 3192.90 \\
\hline
\end{tabular}

DM: Dry Matter; CP: Crude Protein; EE: Ether Extract; CF: Crude Fiber; SBM: Soybean Meal; PKB processed kidney bean; T1 100\%SBM: 0\%PKB; T2: 75\%SBM: 25\%PKB; T3: 50\%SBM: 50\%PKB; T4: 25\%SBM: $75 \%$ PKB; T5 0\%SBM: $100 \%$ PKB

Table 4: Nutritional composition of treatment diets containing different levels of processed kidney bean as a replacement for soybean meal. 
content of CF of PKB and the further reduction as a result of boiling might favored the feed intake of the layers by decreasing the problem of feed digestibility $[24,25]$

SBM and NSC are rich in CP content that make these ration to be ideal source of protein supplement for poultry. The NSC used to formulate experimental ration composed $26 \% \mathrm{CP}$ and $2006 \mathrm{kcal} \mathrm{ME}$. The CP values are comparable with that of Shewangzaw et al. and Meseret et al. but low in ME [26,27]. Previously under taken studies indicated that the CP content of SBM to be in the range of 41 to $50 \%$ $[28,29]$. However, similar to the value obtained in this study, a $38 \% \mathrm{CP}$ content of SBM were reported in Ethiopia [27].

When SBM and PKB are compared, SBM contain by far higher $\mathrm{CP}, \mathrm{EE}$ and ME. On the other hand, PKB has lower CF and ash than SBM. As a result, the $\mathrm{CP}$ of the formulated ration ranged between $16 \%$ (diet 5) and 18\% (diet 1). Crude fiber increased, EE decreased because of total replacement of SBM by PKB. The energy content of SBM is higher than that of PKB. For this reason, the energy content decreased with increasing level of processed kidney bean. Nevertheless, energy and protein content of all rations ranged within the recommended level for layers. Lesson and summer recommended $16-18 \%$ of $\mathrm{CP}$ and 2500-3300 kcal/kg ME, respectively for white leghorn layers [30]. Furthermore, the energy of compound ration is the same with that used by Zebiba and Senayt et al. in their experiment for the same bird in the same farm [31,32].

\section{Fertility and hatchability of eggs}

Mean values of fertility and hatchability for the treatments are presented in Table 5. The logistic regression results for fertility and hatchability of eggs showed no significant difference among treatments. However, there was a numerical decrease in fertility and hatchability percentage for $\mathrm{T} 5$ as compared to 11 which is similar with Sisay et al. finding [7]. The numerical decrease in fertility and hatchability from T1 to $\mathrm{T} 5$ could be the result of increased, level of kidney bean in the ration that caused reduction of level of protein, calcium and phosphorus found in the rations. The diets of breeder poultry should be adequate in both quantity and quality to meet the recommended levels of feed standard [2]. The level of dietary protein significantly affected egg fertility and hatchability. Poor hatching happen when nutritionally deficient feed is used for layers [33]. The authors have shown that low calcium levels tended to decrease percent of fertility and hatchability. On the contrary, El-Ghamry et al. reported improved fertility ( $83 \%$ and $77 \%$ ) and hatchability ( $78 \%$ and $71 \%$ ) for the group fed $2.4 \%$ and $2.6 \%$ calcium, respectively [34].

\section{Embryonic mortality}

The mean values of embryonic mortality at different stages of development are presented in Table 5. The logistic regression result showed no significant differences among treatments for early, mid, late and pip embryonic mortality. Nevertheless, the mortality tends to numerically increase with increased level of PKB compared to control diets that do not contain PKB. This might occurred because of the decreased crude protein level with increased level of PKB. Embryonic mortality of eggs of breeder hens' fed low protein is reported to be higher than hens fed high protein diets. Low-protein rearing rations were associated with higher rates of food intake, higher mortalities and lower rates of egg production than the conventional protein ration Hocking et al. [33].

\section{Chick quality}

Visual scoring (observation): The visual scoring of chicks is presented in Table 6. Wald chi-square statistics indicated that visual scoring of chicks was insignificant (0.64) at $(\alpha=0.05)$ among the treatments, but Sisay et al, indicated that visual scoring of chicken was not significant (pr $>$ chisq $0.641 \alpha=0.05$ ). The visual assessment showed that the quality of chicken is better in the order of $\mathrm{T} 2>\mathrm{T} 1>\mathrm{T} 3>\mathrm{T} 4$, while the chick quality of $\mathrm{T} 5$ is inferior or poor on visual scoring. The chicken in T5 were not well standing, they are dehydrated and seems inactive at their day old age. This assessment was supported by length and weight of chicks that indicated significant differences among treatments. Utilization of visual score parameters such as naval quality, firmness of leg, size of beak, eye and vital chick are recommended ways of determining highest quality chicks Petek et al. [35].

Chick length: The length of chicks hatched from eggs of hens fed diet containing $0,25,50$ and $75 \%$ of PKB are not significantly different which is similar with Sisay et al. finding that there was no significant difference ( $p>0.05)$ among treatments in chick weight and chick length [7]. However, the chicken hatched for eggs harvested from layers fed $100 \%$ PKB (T5) had significantly lower length as compared to that from the layers fed SBM at different levels. This occurred either because of the egg size that accommodate larger embryo of chicken compared to the small eggs that has less environment to hold large chicken or the nutrition of the layers that promote better growth of the chicks. Mukhtar et al. found similar result and stated that hatching length is an easy and repeatable quality evaluation parameter for newly hatched chicks [36]. This important trait has a positive correlation with the size of the egg and the chick's weight. It is an important economic trait to predict chick development because it is positively related to yolkfree body mass at hatch and potential of chicks for optimum future performance.

Furthermore, Petek et al. pointed out that each extra $\mathrm{cm}$ of hatchling length at day of hatch meant an increase of $18 \mathrm{~g} \mathrm{BW}$ at seven

\begin{tabular}{|c|c|c|c|c|c|c|c|}
\hline & \multicolumn{7}{|c|}{ Treatments } \\
\hline Parameter & T1 & T2 & T3 & T4 & T5 & SEM & SL \\
\hline Fertility (\%) & 94.87 & 94.87 & 94.87 & 94.87 & 92.3 & 2.29 & NS \\
\hline HTES (\%) & 71.79 & 71.79 & 71.79 & 64.10 & 61.54 & 4.59 & NS \\
\hline HFES (\%) & 75.43 & 75.64 & 75.43 & 69.44 & 66.67 & 3.50 & NS \\
\hline EEM (\%) & 5.56 & 5.56 & 5.56 & 8.33 & 8.33 & 2.14 & NS \\
\hline MEM (\%) & 5.56 & 8.12 & 8.12 & 11.11 & 8.33 & 1.76 & NS \\
\hline LEM (\%) & 5.56 & 5.56 & 5.56 & 8.30 & 13.89 & 2.48 & NS \\
\hline PIEM (\%) & 10.89 & 8.12 & 10.89 & 11.11 & 11.11 & 3.07 & NS \\
\hline
\end{tabular}

SBM: Soybean Meal; PKB: Processed Kidney Bean; T1: 100\% SBM:0\% PKB; T2: $75 \%$ SBM:25\%PKB; T3: 50\%SBM:50\%PKB; T4: 25\%SBM:75\%PKB; T5: 0\%SBM:100 PKB; HTES: Hatchability on Total Egg Set; HFES: Hatchability on Fertile Egg Set; EEM: Early Embryonic Mortal; MEM: Mid Embryonic Mortality; LEM: Late Embryonic Mortality; PIEM: Pip Embryonic Mortality.

Table 5: Fertility and hatchability of eggs and embryonic mortality in layers fed different levels of processed kidney bean as replacements to soybean meal.

\begin{tabular}{|c|c|c|c|c|c|c|c|}
\hline & \multicolumn{7}{|c|}{ Treatment } \\
\hline Parameters & T1 & T2 & T3 & T4 & T5 & SEM & SL \\
\hline Visual (\%) & 84.93 & 85.09 & 82.36 & 81.02 & 70.83 & 3.89 & NS \\
\hline Length (cm ) & $15.63^{\mathrm{a}}$ & $15.00^{\mathrm{a}}$ & $15.33^{\mathrm{a}}$ & $15.03^{\mathrm{a}}$ & $14.33^{\mathrm{b}}$ & 0.20 & * \\
\hline Weight (g) & $34.13^{\mathrm{a}}$ & $34.20^{\mathrm{a}}$ & $33.13^{\mathrm{a}}$ & $33.06^{\mathrm{a}}$ & $32.47^{\mathrm{b}}$ & 0.28 & $*$ \\
\hline
\end{tabular}

${ }^{a-b}$ Means in the row without common superscript are significant; NS: NonSignificant, SL: Significance Level; SEM: Standard Error of Mean ; cm: Centmeter, g: Gram;\%: Percent; PKB: Processed Kidney Bean Meal; SBM: Soybean Meal; T1: $100 \%$ SBM:0\% PKB; T2: 75\%SBM: 25\%PKB; T3: 50\%SBM: 50\%PKB; T4 25\%SBM: 75\%PKB; T5: 0\%SBM: 100 PKB.

Table 6: Chick quality parameters of white leghorn layers fed different levels of processed kidney bean as a replacement to soybean meal. 
Citation: Hussein T, Urge M, Animut G, Fikru S (2015) Effects of Feeding Processed Kidney Bean Meal (Phaseolus vulgaris) by Replacing Soybean Meal on Egg Fertility and Qualities of Chicks of White Leghorn Hens. J Veterinar Sci Technol S12: 001. doi:10.4172/2157-7579.S12-001

Page 5 of 6

days of age [35]. Chicks with longer hatchling length have better-feed efficiency and survival rates as compared to smaller chicks. Petek et al. Classified length intervals in to short, middle and long for a day old chicks [37]. Accordingly, layer chick with a length of $<17.8,17.8$ 18.2 and $>18.2 \mathrm{~cm}$, respectively are grouped as short, medium and long chicks. As to this classification, chick lengths in the present experiment for all treatments fall within a short category. On other hand, Petek et al. reported that the body weight and chick length uniformity in long group in all poultry to be better than the shorter group [38].

Chick weight: The chick weight of layers were higher $(\mathrm{P}<0.05)$ in ration that do not contain SBM as compared to the ration containing $100 \% \mathrm{PKB}$ (Table 6). The variation in chick weight may be due to the weight of eggs, which is slightly decreasing across treatment as well as the amino acid content of the rations, which is higher in control diet while decreasing across treatment because of decreased SBM. The present finding is in agreement with many previous of findings. For instance the chicks injected with amino acids invariably had higher plasma protein and lower plasma glucose on the day of hatch, because methionine and threonine are critical for the growth of chicken embryo [39]. Egg weight has a direct impact on the weight of chick and there is a positive correlation between egg and chick weight [35]. Chicken hatched from large eggs are heavier than those hatched from comparatively smaller eggs [40]. A heavy chick indicates a good development. However, this is sometimes not true and evaluating chick quality by measuring only body weight can be misleading [41].

\section{Conclusion}

The study was undertaken to evaluate the effect of substituting processed red kidney bean (PKB) for soybean meal (SBM) as a protein source on fertility, chick quality, and embryonic mortality of white leghorn layers at Haramaya university poultry farm. The feed of the layers were composed of corn grain, wheat short, soybean meal, kidney bean, noug seed cake, limestone, vitamin premix and salt. PKB, SBM and noug seedcake were used as protein source contain 28,38 and $26 \%$ $\mathrm{CP}, 0.9,7$ and $6 \% \mathrm{CF}, 7,9$ and $6 \%$ ash, respectively and metabolizable energy content of 3182.2, 3215 and $2006 \mathrm{Kcal} / \mathrm{kg} \mathrm{DM}$, respectively.

Hundred eighty white leghorn layers and 30 cocks of the similar age and weight were randomly allotted into five treatments using complete randomized design, in which each treatment replicated three times. In each treatment, the kidney bean was replaced soybean meal. The five treatments ration were composed of T1 $(0 \% \mathrm{PKB}+100 \% \mathrm{SBM})$, T2 (25\% PKB+75\%SBM), T3 (50\%PKB+50\%SBM), T4 (75\%PKB+25\% $\mathrm{SBM})$ and $\mathrm{T} 5(100 \% \mathrm{PKB}+0 \% \mathrm{SBM})$. Diet were formulated to contain 16.0-16.5\% CP and 2800-2900 Kcal ME/kg DM based on pre analyzed nutrient contents of the feed ingredients used for the experiment. The experimental house consisting of fifteen pens was cleaned and disinfected to prevent infectious and parasite diseases two days prior to placing the birds into pens. The feed and water were given ad libtum. The feed was given at 8 am and 2 pm by diving the daily offer into two equal portions fertility, hatchability, embryonic mortality and chick quality were evaluated.

Chick weight and chick length were analyzed by ANOVA procedure of GLM, while fertility, hatchability, embryonic mortality and chick quality were analyzed by logistic regression model using SAS 2004 version 9.0 computer software. The differences between means were separated by using Tukey Method.

Fertility, hatchability, embryonic mortality and visual chick quality assessment were not significantly $(\mathrm{P}>0.05)$ different between the treatments. Chick length and weight were $15.63,15.00,15.33,15.03$ and $14.33(\mathrm{SEM} \pm 0.02)$ and $34.13,34.20,33.13,33.06$ and 32.47 (SEM $\pm 1.39)$ ) for $\mathrm{T} 1, \mathrm{~T} 2, \mathrm{~T} 3, \mathrm{~T} 4$ and $\mathrm{T} 5$, respectively significantly $(\mathrm{P}<0.05)$ lower for $\mathrm{T} 5$ as compared to the rest treatments

\section{Acknowledgement}

The authors' heartfelt appreciation goes to the Ethiopian Ministry of Education (MOE) for fully sponsoring this study and Haramaya University for provision of research facilities.

\section{References}

1. Tona K, Bruggeman V, Onagbesan O, Bamelis F, Gbeassor K (2004) Effects of age of broiler breeder and egg storage on egg quality, hatchability, chick chick weight and quality chick post-hatch growth to forty-two days. Japr 13: 10-18.

2. Brillard JP (2007) Control of fertility in turkeys: the impact of environment nutrition and artificial reduction by maternal diets high in unsaturated fatty insemination technology. Poultry Industry Technical articles.

3. Hullet RM (2007) Managing incubation: where are we and why? Poult Sci 86: 1017-1019.

4. Akobundu ENT, Cherry JP, Simmon JG (1982) Chemical, functional and nutritional properties of 'Egusi' (Colocynthis citrullus) seed protein products. $J$ Food Sci 47: 828-835.

5. Tropical Legumes, resources for the future (1979) National Academy of Science (NAS). Washington DC pp. 150-168.

6. Wilson KJ, Beyer RS (2000) Poultry Nutrition Information for the Small Flock. Kansas State University Agricultural Experiment Station and Cooperative Extension Service.

7. Sisay Fikru M, Mengistu Urge L, Getachew Animu (2015b) Effects of Replacing Soybean Meal with Processed Kidney Bean Meal (Phaseolus vulgaris) on egg fertility and chick quality of White Leghorn Hens. J Adv Vet Anim Res 2: 146152.

8. AOAC (Association of Official Analytical Chemist) (1990) Official Method of Analysis (13thedn) AOAC Arlington, Verginia, USA. pp. 12-98.

9. Wiseman J (1987) Feeding of Non-Ruminant Livestock. Butterworth and C Ltd $370 \mathrm{p}$.

10. North Mack O (1984) Commercial Chicken Production Manual (3rdedn) AVI Publishing Company, Inc. West Port, Connecticut, Georgia, p, 451.

11. Butcher GD, Nilipour AH (2009) Chicken Embryo Mal positions and Deformities Institute of Food and Agricultural Sciences, University of Florida.

12. Rashed M (2004) Effects of feeding systems on the egg production of Fayoum hens of model breeding unit under PLDP programin Bangladesh. MScThesis.

13. SAS (Statistical analysis system) (2008) SAS user guide. Version 9.0 institute Inc NC.

14. Gomez KA, Gomez AA (1984) Statistical Procedures for Agricultural Research (2ndedn), John Willey and Sons, New York, p. 720.

15. Arija I, Centeno C, Viveros A, Brenes A, Marzo F, et al. (2006) Nutritional evaluation of raw and extruded kidney bean (Phaseolus vulgaris L. var. pinto) in chicken diets. Poult Sci 85: 635-644.

16. Audu SS, Aremu MO (2011) Effect of processing on chemical composition of red kidney bean (Phaseolus Vulgaris L.) Flour. Pakistan journal of Nutrition 10 1069-1075.

17. Sisay Fikru M, Mengistu Urge L, Getachew Animu (2014) Effects of Replacing Soybean Meal with Processed Kidney Bean Meal (Phaseolus vulgaris) on Egg Production of White Leghorn Hens. World Applied Sciences Journal 32: 19181926.

18. Sisay Fikru M, Mengistu Urge L, Getachew Animu (2015a) Effects of Replacing Soybean Meal with Processed Kidney Bean Meal (Phaseolus vulgaris) on qualities of Eggs of White Leghorn Hens. International Journal of Agricultural Science Research 4: 49-56.

19. Marzo F, Alonso R, Urdaneta E, Arricibita FJ, Ibáñez F (2002) Nutritional quality of extruded kidney bean (Phaseolus vulgaris L. var. Pinto) and its effects on growth and skeletal muscle nitrogen fractions in rats. J Anim Sci 80: 875-879.

20. Emiola IA (2011) Processed african yam bean (sphenostylis stenocarpa) 
Citation: Hussein T, Urge M, Animut G, Fikru S (2015) Effects of Feeding Processed Kidney Bean Meal (Phaseolus vulgaris) by Replacing Soybean Meal on Egg Fertility and Qualities of Chicks of White Leghorn Hens. J Veterinar Sci Technol S12: 001. doi:10.4172/2157-7579.S12-001

Page 6 of 6

inbroiler feeding: performance characteristics and nutrient utilization. Journal of Environmental Issues and Agriculture in Developing Countries 3: 123-131.

21. Emiola IA, Ologhobo AD (2006) Nutritional assessment of raw and differen processed Legume seed in Broiler ration. JAVA 5: 96-101

22. Sai-Ut S, Ketnawa S, Chaiwut P, Rawdkuen S (2009) Biochemical and functional properties of proteins from red kidney, navy and adzuki beans. Ajfai 2: 493-504.

23. Ofongo ST, Ologhobo AD (2007) Processed Kidney Bean (Phaseolus vulgaris) in Broiler Feeding: Performance Characteristics. Conference on International Agricultural Research for Development p. 3.

24. Akaerue Blessing I, Onwuka Gregory I (2010) Effect of Processing on the Proximate Composition of the Dehulled and Undehulled Mungbean [Vigna radiata (L.) Wilczek] Flours. PJN 9: 1006-1016.

25. Mubarak AE (2005) Nutritional composition and anti nutritional factors of mung bean seeds (Phaseolus aureus) as affected by some home traditional processes. Food Chemistry 89(4): 489-495.

26. Shewangizaw Wolde, Tegene Negesse, Aberra Melesse (2011) Effect of dietary protein concentration on feed intake, body mass gain and carcass traits of Rhode Island Red chicken. Journal of Science and Development 1: 53-64.

27. Meseret Girma, Mengistu Urge, Getachu Animtu (2011) Ground Prosopis Juliflora poods as feed ingredient in poultry Ration: Effects growth and carcass characteristics of Broiler. International journals of poultry Sciences 10: 970-976.

28. Waldroup WP (2002) Soybean meal in poultry nutrition. Poultry science, 0.210 faretteville AR 72701. Arakansas.

29. Eekeren AN, Maas HW, Saatkamp, Verschuur M (2006) Small Scale Chicken Production. Digigrafi, Wageningen press, Netherlands 99p.

30. Leeson S, Summers JD (2001) The Nutrition of Chicken (2ndedn) University Books, Guelph, Canada 355p.

31. Zebib Abisa (2012) Effects of substituting sorghum for maize on egg production, quality, fertility and hatchability of white leghorn layers. M.sc Thesis, Haramaya University, Haramaya.

32. Senayt Abraha (2011) the effect of feeding different levels of soybean meal on egg production, quality, fertility and hatchability of white leghorn layers. M.sc Thesis, Haramaya University, Haramaya.

33. Hocking PMR, Bernard, Robertson GW (2002) Effects of low dietary protein and different allocations of food during rearing and restricted feeding after peak rate of lay on egg production, fertility and hatchability in female broiler breeders. British Poultry Scienc, 43: 94-103.

34. El-Ghamry, El-Allawy, Hewida, Yassein MSA, El Mallah GM (2010) Evaluation of Rationary Calcium Requirements in Fayoumi Laying Hens. Iranian Journa of Applied Animal Science 1: 81-86.

35. Petek M, Orman A, Dikmen S, Alpay F (2010) Physical chick parameters and effects on growth performance in broiler. Archiv Tierzucht 53: 108-115.

36. Mukhtar N, Khan SH, Anjum MS (2013) Hatchling length is a potential chick quality parameter in meat type chickens. World's Poultry Science Journal 69 889-895.

37. Petek M, Orman A, Ddkmen S, Alpay F (2009) Relations between day - old chick length and body weight in broiler, quail and layer. Turkey Journal of Animal Sciences 27: 25-28.

38. Petek M, Orman A, Dikmen S, Alpay F (2008) Relations between dayold chick length and body weight in broiler, quail and layer. Journal of Veteriner Fakültes Dergisi, Uludag? Üniversitesi 27: 25-28.

39. Subrat K, Bhanja, Asit, Baran, Mandal, et al. (2012) Modulation of Post hatchgrowth and immune competence through in ovo injection of limiting amino acids in broiler chickens. Indian Journal of Animal Sciences.

40. Al-Murrani WK (1978) Maternal effects on embryonic and postembryonic growth in poultry. Br Poult Sci 19: 277-281.

41. Molenaar R (2009) Evaluations of chick quality; which method do you choose? HatchTech BV, the Netherlands. 